\title{
Late cuts: an international look at adult circumcision
}

$\mathrm{M}$ ost circumcised men have no recollection of the procedure that claimed their foreskins. A human brain retains little, if any, of what its owner experiences during infancy, when the vast majority of circumcisions occur. But there are some men who not only remember their circumcisions, they booked the appointments themselves.

Adult circumcision is not as common as infant circumcision, but it's not exactly uncommon either. In a few countries, actually, the practise is thriving. Some men do it to improve hygiene or because they believe a hoodless penis looks better. Others do it for reasons related to health, religion or peer pressure.

African countries with high HIV rates have seen the largest bump in adult circumcision in recent years, following clinical trials in South Africa, Kenya and Uganda that found circumcised men are $51 \%-60 \%$ less likely to contract the virus from heterosexual intercourse than their intact countrymen (PLoS Med 2: e298. doi: 10.1371/ journal.pmed.0020298 and Lancet 2007;369:643-56 and Lancet 2007; 369:657-66).

"The true benefits exceed risks by an astronomical amount," Brian Morris, professor of molecular medical science at the University of Sydney in Australia, writes in an email. "At the same time, the claims that male circumcision somehow leads to impaired sexual function, sensitivity, sensation during arousal or satisfaction has been disproven by just about every good research study."

Morris has written extensively on the health benefits of circumcision, claiming in one paper that it is a "biomedical imperative" (BioEssays 29:1147-58). The data from the African trials, he notes, has convinced several international organizations to support mass circumcision. "In March 2007, the WHO [World Health Organisation] therefore endorsed circumcision as an important additional weapon in the fight against

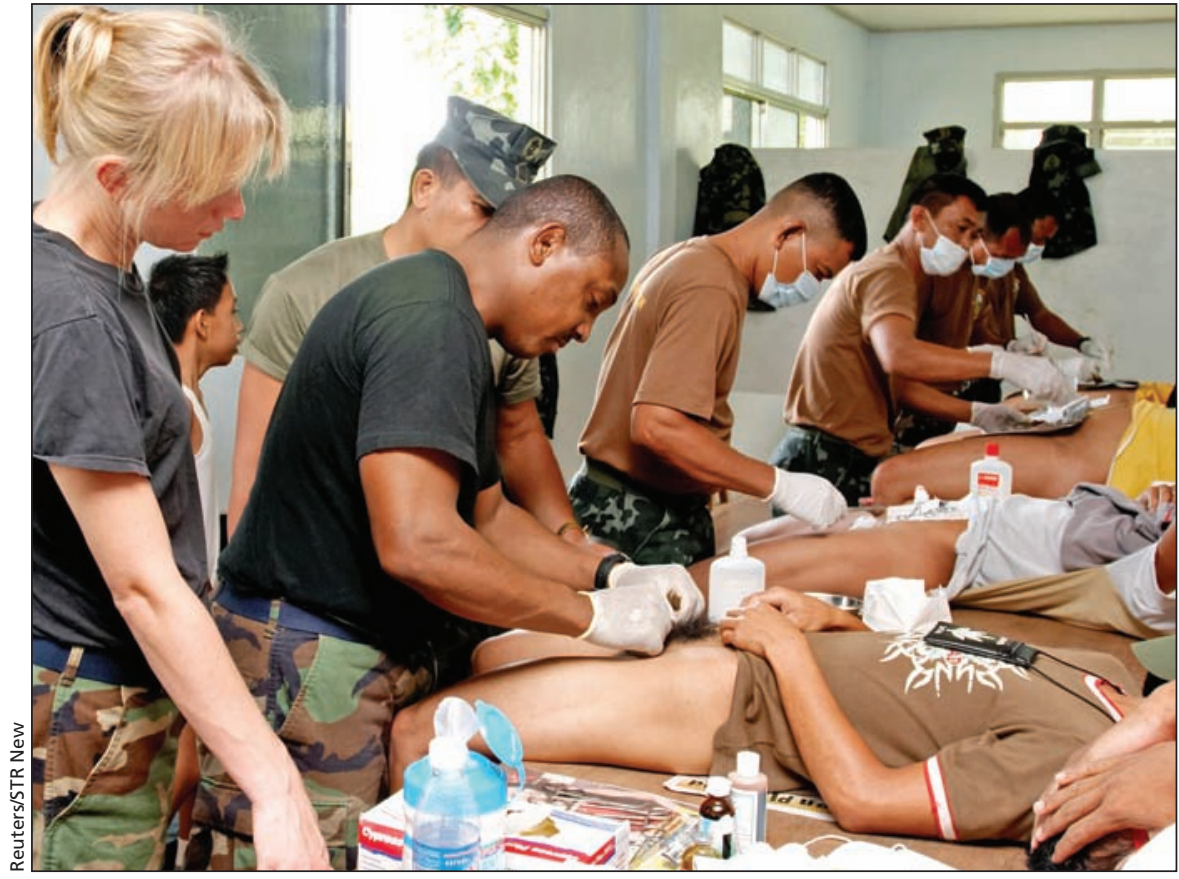

Some adults choose to be circumcised for religious reasons, such as these Muslim men who received the procedure at a military base in Marawi City in the Philippines.

AIDS," he states in the paper. "The WHO, UNAIDS and others have done projections estimating the millions of lives that will be saved by implementation of circumcision, which has been equated to an effective vaccine."

The African clinical trials have led to nationwide campaigns in some countries to promote mass circumcision for adult men. Swaziland, for instance, has been encouraging men to go under the knife since 2006. Rwanda hopes to cut the rate of transmission of HIV within its borders in half by getting two million men to volunteer for circumcision, a target the country's health minister estimates it will reach by 2013 (www.cmaj.ca/look up/doi/10.1503/cmaj.109-3950).

There are no national movements to increase adult circumcision in North America, though the procedure may be increasing slightly in some areas. A possible explanation is that, due to falling rates of infant circumcision in recent decades, more young men are intact and seeking the procedure for cosmetic reasons. After all, women seem to favour the appearance of circumcised penises. In one survey, for example, $90 \%$ of women said circumcised penises look better, $92 \%$ said they were cleaner and $85 \%$ said they were more pleasant to touch ( $J$ Sex Educ Ther 1988;14:8).

"For my practice, it seems the number of men seeking circumcision is increasing," Dr. David Cornell, a urologist who runs The Circumcision Center in Atlanta, Georgia, writes in an email. "I suspect this would not be true for most urology practices, but for my practice, over $95 \%$ of men seeing me for circumcision are motivated by cosmetic, aesthetic and social reasons. I would guess that in most urology practices, the majority of patients would be doing it for medical reasons.'

In Canada, men must cite a valid medical reason for the procedure if they want it to be covered by health insurance. "Unfortunately, some guys do have problems," says Dr. John Aquino, medical director of Ontario Men's Health, a Toronto-based specialty clinic that offers adult circumcision. "They 
can't retract their foreskins and can even have trouble urinating."

Even if they have these or other problems, such as painful erections or pain during intercourse, men seeking the procedure in Ontario could be in for a long wait. Some hospitals are reluctant to commit operating time for adult circumcisions, says Aquino, who has seen some men wait for more than two years to shed their foreskins.

"It's a pretty simple procedure. The healing phase puts some people off. They have to put aside a month when they will not be sexually active. They can't do physical jobs for several weeks," says Aquino, who notes that risks for excessive bleeding, infection and scarring are minor, though of course possible, as for any surgery.

Another reason some adults opt for circumcision, even if they don't have operational issues, is religious conversion. Men entering the Jewish faith, for instance, are encouraged to lose their member-hoods. In one study of 42 men circumcised as adults, 39 cited religious reasons (Urology 2004;63:155-8). The participants reported no statistically significant adverse effects after their operations, though there was an increase in their "ejaculatory latency" (the time it took them to ejaculate during sex), which the authors concluded "can be considered an advantage rather than a complication."
Other studies, however, did find some negative effects. In one, which mostly included men seeking circumcision for health problems such as phimosis, balantis and condyloma, $32 \%$ of participants reported problems, including a decrease in erectile function and sensitivity (J Urol 2002; 167:2113-6). In another study, $20 \%$ of circumcised adults said their sex lives had worsened and $48 \%$ reported a decrease in pleasure from masturbation (BJUI 2007; 99:619-22).

The latter study was conducted in South Korea, which may be the only country on earth where the majority of men are circumcised but not as infants, and do so for reasons unrelated to health, religion or aesthetics. According to one paper, almost $85 \%$ of males 16-39 years old are circumcised in South Korea, the vast majority around the age of 12 (BJUI 1999;83:28-33).

No one can say for certain how the country came to embrace circumcision so quickly - the procedure was basically unheard of there in the 1940s though the prevailing theory is that South Korean men were influenced by circumcised American soldiers during the Korean War in the 1950s. "Within a decade, South Koreans came to believe that practicing circumcision was 'advanced and modern,' just like the American soldiers," US sexologist Robert Francoeur wrote (http://gkorea .nayana.com/s1.html). "If Americans did it, it must be good."

In the 1960s, South Korea's doctors made a big push for circumcision, launching a widespread media campaign promoting it as better for hygiene and health. Since then, the practice has become the cultural norm. "Korea has no religious background, it is nevertheless practised during adolescence, largely initiated by peer pressure," states the South Korean study. "Therefore, it has partly become a 'rite of passage' and is fully integrated into present Korea culture." Roger Collier, CMAJ

CMAJ 2012. DOI:10.1503/cmaj.109-4013

Editor's note: Fourth of a six-part series

Part I: Circumcision indecision: the ongoing saga of the world's most popular surgery

(www.cmaj.ca/lookup/doi/10.1503

/cmaj.109-4021).

Part II: Vital or vestigial? The foreskin has its fans and foes

(www.cmaj.ca/lookup/doi/10.1503

/cmaj.109-4014).

Part III: Whole again: the practice of foreskin restoration

(www.cmaj.ca/lookup/doi/10.1503

/cmaj.109-4009). 